\title{
Attitudes of teachers towards inclusion of students with disabilities in physical education: Validity of the ATIPDPE-R instrument in Polish cultural context
}

\author{
Monika Cyran ${ }^{1, *}$, Martin Kudláček ${ }^{2}$, Martin Block ${ }^{3}$ Iwona Malinowska-Lipieńn \\ and Joanna Zyznawska ${ }^{1}$ \\ ${ }^{1}$ Medical College, Jagiellonian University, Krakow, Poland; ${ }^{2}$ Faculty of Physical Culture, Palacký University Olomouc, \\ Olomouc, Czech Republic; and ${ }^{3}$ Curry School of Education, University of Virginia, Charlottesville, VA, USA
}

Copyright: (C) 2017 M. Cyran et al. This is an open access article licensed under the Creative Commons Attribution License (http://creativecommons.org/licenses/by/4.0/).

\begin{abstract}
Background: Following the inclusion of children with disabilities in mainstream schools worldwide, legislative changes have recently been introduced in Poland, facilitating educational inclusion of individuals with disabilities. However, practical implementation still requires further action. Attitudes are a major determinant of teachers' behavior. Therefore, based on the Theory of Planned Behavior, the instrument Attitudes Toward Teaching Individuals with Physical Disabilities in Physical Education (ATIPDPE) has been developed, and adapted to cultural contexts in several countries (e.g. South Africa, Slovenia, and Greece). Objectives: The aim of this study was to estimate construct validity of the revised ATIPDPE-R instrument to the Polish cultural context (ATIPDPE-R-PL), in order to prepare a reliable scale to measure the attitudes of physical education (PE) teachers towards teaching students with physical disabilities in general PE classes. Methods: Participants were 158 in-service PE teachers (100 women and 58 men, range of age from 25 to 60, from primary and secondary schools) from Polish schools. Construct validity was obtained throughout the principal component analysis method (PCA). Reliability was estimated through Cronbach's alpha coefficient, where the value of at least .7 was accepted as satisfactory. Results: Based on the analysis, the attitudinal scale of ATIPDPE-R-PL measured three psychological components, which came from the PCA, and explained $66 \%$ of the variance similar to the original scale. Conclusions: The three components were positive and negative outcomes for students and negative outcomes for teachers, however items in each component varied from the original scale.
\end{abstract}

Keywords: inclusion, physical education, attitudes, Theory of Planned Behavior, construct validity

\section{Introduction}

In the European Union the majority of countries encourages equality for people with disabilities, and promotes inclusive education as the preferred option. These countries have formulated their own legislation and have been implementing inclusive education in different ways that reflect their social, cultural and historical contexts (Hardman, 2008). In countries that have implemented the inclusion concept, the attitudes of physical educators have become the subject of research (e.g. Bartoňová, Kudláček, \& Bressan, 2007; Di Nardo, Kudláček, Tafuri, \& Sklenaříková, 2014; Doulkeridou, Evaggelinou, \& Kudláček, 2010; Táboas-Pais

\footnotetext{
* Address for correspondence: Monika Cyran, Department of Physiotherapy, Faculty of Health Sciences, Medical College, Jagiellonian University, ul. Medyczna 9, 30-688 Kraków, Poland. E-mail: m.brzostek@uj.edu.pl
}

\& Rey-Cao, 2012). Reports claim that attitudes of physical education teachers (PET) towards including students with disabilities in their classes relate to their knowledge about special needs of the students with disabilities (Papadopoulou, Kokaridas, Papanikolaou, \& Patsiaouras, 2004; Tripp \& Rizzo, 2006).

Following the example of other countries, in Poland within the last decade, educators who have been involved in European Adapted Physical Activity projects, have initiated the inclusion movement in physical education (PE). In 2008 a group of adapted physical specialists have established Polish Scientific Association of Adapted Physical Activity. The main idea of the association is to promote the practices of adapted physical education in the school and community environment, conduct adapted physical activity related research and prepare guidelines to introduce adapted physical education in schools (MorgulecAdamowicz et al., 2015). PE is an obligatory subject in 
all Polish schools - often perceived to have a marginal role. Although it is compulsory in mainstream education, children with disabilities are often excused from classes for medical reasons, lack of knowledge of teachers, lack of facilities or have physical therapy instead. It is a challenge for the majority of schools to ensure the same high quality physical education for all students. Therefore, PE teachers need to gain confidence and knowledge to meet the needs of young people with disabilities (Morgulec-Adamowicz et al., 2015).

Integration and inclusion in Polish society started at the beginning of the 1990s. However, in general PE is a new phenomenon that will require the involvement of educators and the support of decision makers (Bełza, 2014; Omianowski, 2008). According to the data provided by the Polish Central Statistical Bureau, in the 2013/2014 school years, there were about 160,000 students with disabilities in primary, middle and secondary schools (System Edukacji Oświatowej, 2014). Children with physical disabilities (PD) have been systematically included into general schools; nevertheless the area of their physical education has been overlooked. In primary schools (age 6-9), which provide integration education, the decision on the amount of PE classes depends on the individual teacher. This contradicts the obligatory general physical education practice of 3 PE classes (45 min each) per week (Polish Ministry of National Education, 2014). Moreover, PE curricula are designed for the physically able and traditionally place emphasis on competition, leading to winning as an essential component of the PE experience. Adherence to traditional pedagogical approaches is a basic cause of exclusion in PE. Including children with disabilities requires curriculum change, choosing appropriate adaptations to rules, equipment and skills. However, it appears that PE teachers perceive themselves as lacking the knowledge to teach children with disabilities and enable their participation. It is likely for students to become passive observers and have no interaction (Bełza, 2014; Morgulec-Adamowicz et al., 2015).

It is important to investigate and understand teachers' attitudes and beliefs in educational settings, since they have a profound influence on the successful implementation of inclusion (Avramidis \& Norwich, 2002). Attitude has been defined and interpreted by many scholars (i.e. Breckler \& Wiggins, 1992; Zimbardo \& Leippe, 1991), yet it is commonly defined as a positive or negative expression of one's tendency towards objects, people, events or behavior. Certainly, PE teachers must possess requisite knowledge and skills pertinent to their profession, but more importantly, they should strive to develop positive intentions, beliefs and attitudes towards the classroom environment (Sherrill \& O’Connor, 1999). Therefore professional preparation of teachers should likewise focus on attitude and behavior under the variety of circumstances (Kudláček, Válková, Sherrill, Myers, \& French, 2002).

The literature presents the assumptions that it is possible to predict behavior of individuals from their attitudes towards performing such behaviors and that attitudes correspond with behavior (Ajzen, 2005). The behavioral beliefs about perceived consequences of behavior determine one's attitude toward the behavior. According to Ajzen (2005) "each behavioral belief links the behavior to a certain outcome" (p. 123), and "by multiplying beliefs strength and outcome evaluation, and summing the resulting products, we obtain an estimate of the attitude towards behavior" (p. 123), this model states that the stronger positive belief is of the outcome, the more preferable attitude towards performing the behavior. This relation between one's attitudes and behavior is explained in depth in the Theory of Reasoned Action (Ajzen \& Fishbein, 1980) and in its ancillary publication, the Theory of Planned Behavior (TPB; Ajzen, 1991). Using Theory of Reasoned Action and TPB, researches investigated the attitudes of general physical educators, parents and peers in regards to inclusion of students with disabilities (Bartoňová et al., 2007; Downs \& Willams, 1994; Kudláček, Blanková, \& Filipčič, 2007). Already in 1991, Rizzo and Vispoel examined the relationship between professional attributes of PE teachers and their attitudes towards teaching students with intellectual, learning and behavioral disabilities. After examining a comprehensive array of qualities among PET, including perceived competence, academic preparation, work experience and personal character, they found that perceived competence had the strongest relation to attitudes (Kudláček et al., 2007).

This is the first study presenting validation of the Attitude toward Teaching Individuals with Physical Disabilities in Physical Education-Revised (ATIPDPE-R) into Polish language and cultural context (ATIPDPER-PL). The instrument was developed in the Czech Republic based on the TPB to assess attitudes toward teaching individuals with physical disabilities in physical education (Kudláček et al., 2002). The aim of the study is to explore the validity and reliability of the ATIPDPER-PL questionnaire. When validated, the instrument may impact upon the future training of PET in both undergraduate and postgraduate education in Poland.

\section{Methods}

This research has been approved by the Bioethical Committee of the Jagiellonian University in Krakow, Poland. Participation in the survey was voluntary and anonymous. The copies of the survey were distributed 
and collected via targeted on-line survey and in hard copy, during the 2015 annual conferences for PE teachers, organized by the Teachers Regional Excellence Centers. Collection of the data was completed between November and January of the 2015/2016. Out of 300 surveys distributed, 185 were collected (response rate $=61.6 \%$ ). Twenty-seven questionnaires were incomplete, but no surveys with missing answers were included in further analyses.

\section{Participants}

Participants included 100 females and 58 males. Age and years of experience were collected as a categorical variable: thirty-four were under age 35 , sixty-one between age 35-45 and sixty-three between age 45-60. Ninety-two responders had more than 15 years of experience working in school, sixty-six had less than 15 years of experience. Participants were recruited from five regions of southern Poland (Opole, Katowice, Kielce, Wroclaw and Krakow). The study included PET from elementary to high schools from all types of school. Exclusion criteria consisted of: (1) students of PE, (2) part time teachers and (3) retired PET and those (4) other than PET. A total of 158 surveys, 128 (81.0\%) participants declared previous personal experience with people with PD. Roughly $30 \%(n=48)$ of the studied PET reported having obtained information on the needs of children with PD during PE classes outside university courses. Another, 31 (19.5\%) responders had attended course on the subject during their university studies (Table 1).

\section{Instrument}

The instrument used in this study, the ATIPDPE-R (Attitude Toward Teaching Individuals with Physical Disabilities in Physical Education-Revised), was based on the TPB (Ajzen, 1991). The original version of the ATIPDPE was developed by Kudláček et al. (2002) and designed in Czech and English (Kudláček et al., 2007; Martin \& Kudláček, 2010). The survey created was only applicable for physical disabilities, and the results cannot be extrapolated to other impairments. Subsequently, the initial version was revised in 2007 and named ATIPDPE-R (Kudláček, 2007). Translated and adapted to several cultural contexts, the survey was used to assess the attitudes of pre-service and/ or in-service teachers towards inclusion in PE classes (Bartoňová et al., 2007; Di Nardo et al., 2014; Martin \& Kudláček, 2010). The instrument measures three variables that are significant for including students with PD in general physical education: (1) attitudes towards inclusion, (2) subjective norm towards inclusion in PE, and (3) Perceived Behavioral Control (PBC) in relation to inclusion (O’Brien, Kudláček, \& Howe, 2009).

In order to adapt the tool to new cultural conditions, a multi-step, cross translation procedure was employed. Firstly, the tool was translated from its original language - from English to Polish (forward translation by two native Polish speakers). Next, the Polish version received a backwards translation by two native English speakers. Doulkeridou et al. (2010) and Di Nardo et al. (2014) determined that in order to avert cultural bias, at least two bilingual translators are necessary. The goal of the translation procedure was to secure it's the most precise meaning. The optimal version was compiled and compared with the original as practiced by other authors (Kudláček et al., 2007; Martin \& Kudláček, 2010). The two translators concurred that each of the questions in both the Polish and English versions of the survey elicited the same meaning.

The revised version of the questionnaire includes three main components: (1) positive outcomes for students (questions: 1, 3, 5, 6, 9, 10); (2) negative outcomes for teachers (questions: 2, 4) and (3) negative outcomes for students (questions: 7, 8, 11, 12); (Di Nardo et al., 2014; Martin \& Kudláček, 2010). The introduction to the questionnaire provides detailed instructions on how to complete it, and definitions related to inclusion and PD. Next, a sequence of questions is used to assess behavioral beliefs towards the

Table 1

Statistics on demographics and educational measures

\begin{tabular}{lcc}
\hline Variable & Frequency $(n)$ & $\%$ \\
\hline Gender & & \\
$\quad$ Female & 100 & 63.3 \\
$\quad$ Male & 58 & 36.7 \\
Personal experience with people with PD & 128 & 81.0 \\
Taking university course related to APA, APE & 31 & 19.5 \\
Courses on APA or APE provided outside of university & 48 & 30.0 \\
\hline
\end{tabular}

Note. $\mathrm{PD}=$ physical disabilities; $\mathrm{APA}=$ adapted physical activity; $\mathrm{APE}=$ adapted physical education . 
inclusion of students with PD in PE (Kudláček et al., 2002). This part contains of 4 intentional statements; 12 behavioral belief statements; 2 normative beliefs; 2 control belief statements. The last part of the survey consists of 14 demographic data questions (Martin \& Kudláček, 2010).

Each question has a 7-point Likert scale answer option, as recommended by Ajzen (2005). The scoring system transforms the answers from a unidirectional 7-point scale ( 1 being the lowest and 7 the highest score) into a bi-directional system from -3 to 3 (Martin \& Kudláček, 2010).

\section{Statistical analysis}

IBM SPSS Statistics (Version 23 for Windows; IBM, Armonk, NJ, USA) was used for treatment of the data. In order to examine the construct validity of the ATIPDPE-R-PL scale, the exploratory factor analysis using the principal component analysis method (PCA) was employed, similar to comparable studies (FolsomMeek \& Rizzo, 2002; Kudláček et al., 2007, 2002). In order to measure the sampling adequacy, the KaiserMeyer-Olkin index was calculated. The number of extracted factors was established based on criteria of eigenvalue higher than or close to 1.0 , and on theoretical interpretation of the extracted factors. Once the factor structure was established, the reliability of the subscales build on particular components was determined (Kudláček, 2007; Kudláček et al., 2002). The reliability of the scale in terms of its internal consistency was estimated using the Cronbach's alpha coefficient, where the value of at least .7 was accepted as satisfactory (Cronbach, 1951).

\section{Results}

The set of analyzed variables was characterized by good sampling adequacy: Kaiser-Meyer-Olkin index was estimated as equal $.899, p<.001$. The factor loadings matrix obtained using PCA without rotation allowed for the extraction of two components. The first one, with the eigenvalue 5.41 , included 8 items $(1,3,5,6,7$, 8,10 , and 12 ) and explained $45 \%$ of total variance. The factor loadings of particular items ranged from .666 to .848 . The second component, with eigenvalue 1.57 , included 4 items $(2,4,9$, and 11), and explained $13.1 \%$ of total variance. The factor loading of each item on the second component ranged from .363 to .588 . Some items overlapped in both components (Table 2).

According to Table 2 the variables included in the ATIPDPE were separated into two groups, positively and negatively correlated. As the non-rotated solution did not provide a clear interpretation of the extracted factor, the varimax-rotated solution was estimated, leading to a factor structure that differed from the original English ATIPDPE-R version. That rotation also separated items in two components. The first component included items: $1,3,5,6,9,10$, and 11 . The majority of the items loaded in the first component can be identified as a positive outcome dimension. However, variable 11 fell far from the others and yielded a negative loading. The second component included items: 2, 4, 7, 8, and 12. All items from the second component can be identified as negative outcomes; item 7 was loaded negatively (Figure 1).

In order to obtain factor structure, which would be clearer for interpretation, additional analyses of the data were conducted using PCA. It revealed that the attitudinal scale of ATIPDPE-R-PL measures three latent variables. However, the sets of items defining particular components and psychological latent traits that may be associated with these components varied from the original version of the ATIPDPE-R (Martin \& Kudláček, 2010). According to these results, the components may be described as: (1) positive outcomes for students (items 1, 3, 5, 6, 9, and 10); (2) negative outcomes for teachers (items: 2, 4, 8, and 12) and (3) negative outcomes for students (items 7 and 11; Table 3).

In this three-component model, most items showed excellent loading, above .70 (Bartoňová et al., 2007; Kudláček, 2007). Only two items (7 and 9) loaded at .538 (in component 3) and .574 (in component 1), respectively. Two items produced double loading (item 7 and 10). Item 10 loaded highly (.740) in the component and moderately (-.409) in the second component, whereas item 7 loaded to similar extent in components 2 (.532) and 3 (.538). The eigenvalue of the first component equaled 5.41 and explained $45 \%$ of the variance. For the second, the eigenvalue was 1.57 and explained $13.1 \%$ of the variance. The third component had an eigenvalue that equaled .950 and explained $7.9 \%$ of variance.

The reliability of the total score using Cronbach's $\alpha$ coefficient was estimated with a total score of $\alpha=.29$. For the first component it equaled $\alpha=.87$. However, when item 9, with the weakest loading factor of .574 was removed, the $\alpha$ coefficient increased to .89 . For the second component, the reliability coefficient equaled .82 , and for the third component, the respective Cronbach $\alpha$ equaled 48 .

\section{Discussion}

Measuring attitudes and beliefs of pre-service and inservice teachers using an international standardized tool such as Physical Educators' Attitude Toward 
Table 2

Matrix of factor loadings for principal component analysis - non-rotated solution

\begin{tabular}{|c|c|c|}
\hline & \multicolumn{2}{|c|}{ Component } \\
\hline & 1 & 2 \\
\hline Eigenvalue & 5.41 & 1.57 \\
\hline Percent of variance explained & 45.0 & 13.1 \\
\hline $\begin{array}{l}\text { A10. Including students with physical disabilities in my PE class will } \\
\text { teach students cooperation. }\end{array}$ & .848 & \\
\hline $\begin{array}{l}\text { A1. Including students with physical disabilities in my PE class will help } \\
\text { students without disabilities to learn to interact with persons with } \\
\text { physical disabilities. }\end{array}$ & .781 & \\
\hline $\begin{array}{l}\text { A3. Including students with physical disabilities in my PE class will } \\
\text { encourage students to learn to help others. }\end{array}$ & .765 & \\
\hline $\begin{array}{l}\text { A6. Inclusion will have a positive effect on the development of personali- } \\
\text { ties of students with physical disabilities (e.g. self-esteem, feeling of } \\
\text { belonging, etc.). }\end{array}$ & .764 & \\
\hline $\begin{array}{l}\text { A5. Including students with physical disabilities in my PE class will teach } \\
\text { students greater tolerance. }\end{array}$ & .750 & \\
\hline $\begin{array}{l}\text { A12. Including students with physical disabilities in my PE class will } \\
\text { reduce the quality of PE lessons. }\end{array}$ & -.707 & \\
\hline $\begin{array}{l}\text { A8. Students with physical disabilities will slow down instructions and } \\
\text { progress in my PE class. }\end{array}$ & -.678 & \\
\hline $\begin{array}{l}\text { A7. Students with physical disabilities will experience discrimination in } \\
\text { my regular physical education classes. }\end{array}$ & -.666 & \\
\hline $\begin{array}{l}\text { A2. Including students with physical disabilities in my PE classes will } \\
\text { make teaching physical education more difficult. }\end{array}$ & -.602 & .531 \\
\hline $\begin{array}{l}\text { A11. Students without physical disabilities will experience discrimination } \\
\text { in my regular physical education classes. }\end{array}$ & -.372 & -.363 \\
\hline $\begin{array}{l}\text { A4. Including students with physical disabilities in my PE class will make } \\
\text { lesson planning and preparation much more difficult. }\end{array}$ & -.535 & .568 \\
\hline $\begin{array}{l}\text { A9. Inclusion will cause my students to have better knowledge about } \\
\text { persons with disabilities. }\end{array}$ & & .463 \\
\hline
\end{tabular}

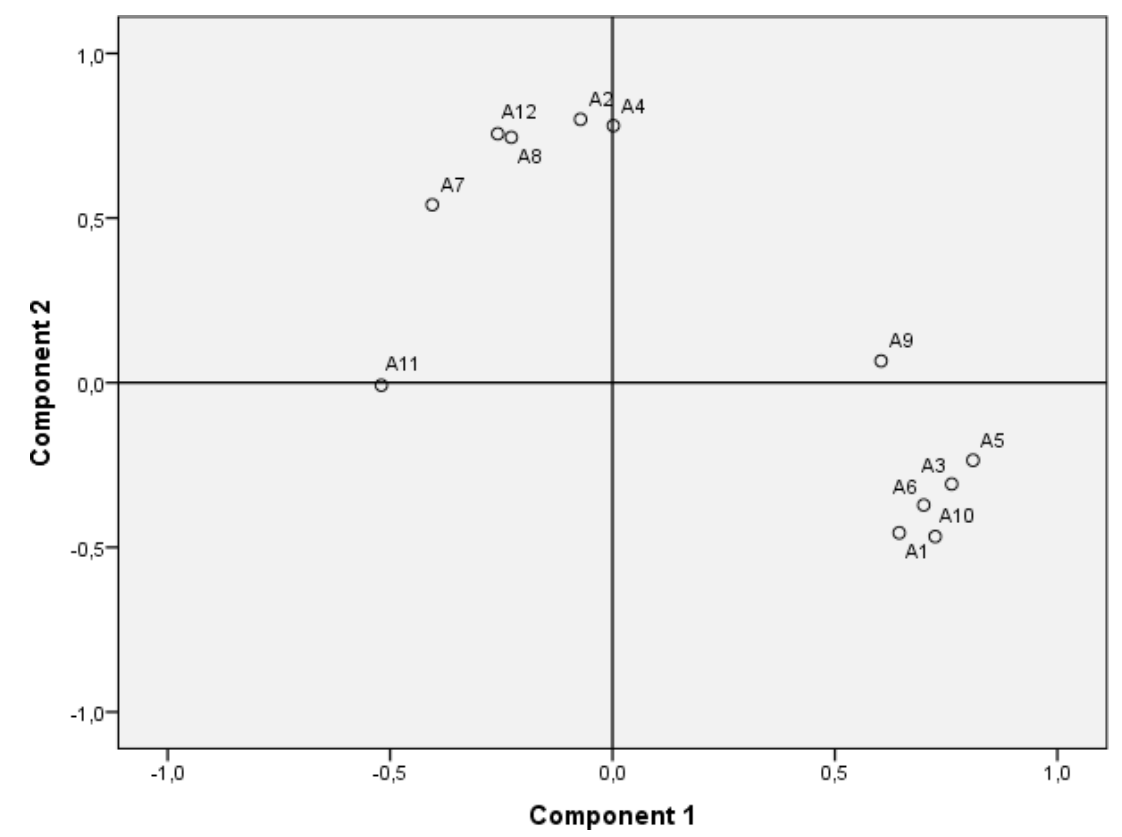

Figure 1. Factor loading plot for the rotated PCA solution. A1-A12 are items of ATIPDPE-R-PL according to Table 2. 
Table 3

Matrix of factor loadings for principal component analysis with varimax rotation

\begin{tabular}{|c|c|c|c|}
\hline & \multicolumn{3}{|c|}{ Component } \\
\hline & 1 & 2 & 3 \\
\hline Eigenvalue & 5.41 & 1.57 & 0.95 \\
\hline Percent variance & 45.0 & 13.1 & 7.9 \\
\hline \multicolumn{4}{|l|}{ Positive outcomes for students } \\
\hline $\begin{array}{l}\text { A1. Including students with physical disabilities in my PE class will } \\
\text { help students without disabilities to learn to interact with persons } \\
\text { with physical disabilities. }\end{array}$ & .724 & & \\
\hline $\begin{array}{l}\text { A3. Including students with physical disabilities in my PE class will } \\
\text { encourage students to learn to help others. }\end{array}$ & .822 & & \\
\hline $\begin{array}{l}\text { A5. Including students with physical disabilities in my PE class will } \\
\text { teach students greater tolerance. }\end{array}$ & .810 & & \\
\hline $\begin{array}{l}\text { A6. Inclusion will have a positive effect on the development of person- } \\
\text { alities of students with physical disabilities (e.g. self-esteem, feeling } \\
\text { of belonging, etc.). }\end{array}$ & .726 & & \\
\hline $\begin{array}{l}\text { A9. Inclusion will cause my students to have better knowledge about } \\
\text { persons with disabilities. }\end{array}$ & .574 & & \\
\hline $\begin{array}{l}\text { A10. Including students with physical disabilities in my PE class will } \\
\text { teach students cooperation. }\end{array}$ & .740 & -.409 & \\
\hline \multicolumn{4}{|l|}{ Negative outcome for students } \\
\hline $\begin{array}{l}\text { A7. Students with physical disabilities will experience discrimination } \\
\text { in my regular physical education classes. }\end{array}$ & & .532 & .538 \\
\hline $\begin{array}{l}\text { A11. Students without physical disabilities will experience discrimina- } \\
\text { tion in my regular physical education classes. }\end{array}$ & & & .916 \\
\hline \multicolumn{4}{|l|}{ Negative outcomes for teachers } \\
\hline $\begin{array}{l}\text { A2. Including students with physical disabilities in my PE classes will } \\
\text { make teaching physical education more difficult. }\end{array}$ & & .792 & \\
\hline $\begin{array}{l}\text { A4. Including students with physical disabilities in my PE class will } \\
\text { make lesson planning and preparation much more difficult. }\end{array}$ & & .778 & \\
\hline $\begin{array}{l}\text { A8. Students with physical disabilities will slow down instructions and } \\
\text { progress in my PE class. }\end{array}$ & & .729 & \\
\hline $\begin{array}{l}\text { A12. Including students with physical disabilities in my PE class will } \\
\text { reduce the quality of PE lessons. }\end{array}$ & & .735 & \\
\hline
\end{tabular}

Teaching Individuals with Disabilities (PEATID III) or the ATIPDPE based on the TPB is considered a meaningful approach to understanding the process of inclusion in many European countries. This approach provides an opportunity to compare Polish results with results from other countries (Folsom-Meek \& Rizzo, 2002; Kudláček, 2007). Similarly to two researches conducted in Slovenia and Greece, this study applied a rigorous approach to translate and validate the instrument ATIPDPE-R into the Polish culture-context (Doulkeridou et al., 2010; Kudláček et al., 2007). The principal component analysis solution with the varimax rotation that was used to explore the structure of the final translation, distinguished two groups of outcomes. These solutions were similar to those that ranged between two initially created scales of ATIPDPE (10-item scale) and ATIPDPE-R (Kudláček, 2007;
Kudláček et al., 2002). However, two items added later to the revised ATIPDPE-R questionnaire, namely no. 11 and no. 12 loaded separately in the Polish version in two different "negative outcomes", whereas in the revised scale they were grouped together under negative outcomes for students. For example, item 11, which originally belonged to the group of negative factors, in the Polish version, was surprisingly located in the first groups with other items having definitely a positive connotation. Although this item was loaded far from the remaining items of this outcome, as visualized on the Figure 1, its loading in this group cannot be easily understood. A potential explanation might refer to the fact that in the context of this sentence, relating to students without disabilities, the meaning of the word discrimination could have been misinterpreted by at least some teachers, as a limitation in achieving the 
possible outcomes rather than a strict discrimination in its literal sematic sense.

In the Polish ATIPDPE-R version, the loadings of the positive items were similar to the original English ATIPDEP-R version (Kudláček, 2007). The items in positive outcomes did not differ from the theory-driven ones and included items 1, 3, 5, 6, 9, and 10. Two of these six positive outcomes loaded higher in comparison with the original work; the other three loaded on the similar level (Kudláček, 2007). The only exception was item 9, which loaded lower in the Polish version .520 in comparison to the original English version (.740; Kudláček, 2007). Such a low loading of this item may be explained by various reasons. Firstly, it might be an insufficient understanding of the principles of inclusion. Analyses of Starczewska, Hodkinson, and Adams (2012), based on their interviews of 10 Polish PET, showed that the concept of inclusion was "not one well recognized by (...) educators” (p. 164). The majority of teachers could not provide a clear definition of inclusion, however when asked to define integration both of these definitions were overlapping. Secondly, according to Zajączkowska (2014) some PET working with students with PD declared that the need to join children into the lessons resulted from their personal ethos rather than their empirical knowledge whereas others showed surprise with the obligation of including all students into PE class. Finally, differences in items loading to the particular factors might also be related to the history of the medical and social model of disability in Poland as well as to the Polish system of higher education for teachers. The relatively rigid medical model reinforced stereotypical thinking and the vocabulary used to define people with disabilities. Some teachers still consider students with disabilities as ill, helpless and deserving pity, compassion and sympathy (Starczewska et al., 2012). However, the Education Research and Development Centre Report (2001) reported a visible evolution into the social perception of people with disabilities, viewed less in a medical context and more as people who are able to face and enjoy life despite all its obstacles.

In the Polish version, negative outcomes for teachers and students loaded differently as compared to previous studies. Namely, in the Polish version, the negative outcomes for teachers included items 2, 4, 8, 12 whereas in the original ATIPDPE-R (Kudláček, 2007) and in other countries such as Australia or Italy (Di Nardo et al., 2014; Martin \& Kudláček, 2010) items 8 and 12 loaded on a negative outcome for student factor. In the Polish version, two elements that concentrated on the discrimination of students with and without disabilities loaded on the negative outcomes for student factor: items 7 and 11 .
Previously, other authors validated the ATIPDPE in non-English speaking countries. In the Slovenian version of the instrument ATIPDPE-SL based on ATIPDPE-R, Kudláček et al. (2007) evaluated the attitude of prospective educators. That study was conducted on a sample of 175 educators enrolled in physical and general education teacher preparation programs in Slovenia (Kudláček et al., 2007). In Poland, only full-time employed teachers were included in the study sample. In another study, Doulkeridou et al. (2010) measured the attitude of Greek PE teachers. That study was conducted in seven different Greek districts with a sampling of 155 registered PET, similar to the Polish study. Nevertheless, that study was based on an early version of the ATIPDPE (Kudláček et al., 2002), while the Polish one used the revised one (Kudláček, 2007). Despite those methodological differences the reliability of measurements done using PCA in the Polish study was comparable to the subscales done in other countries (Greece or Slovenia). The discernable differences between the two original instruments and Polish factor structures do not affect the overall construct reliability. In similar studies in Czech Republic and Greece the three components, which came from the PCA, explained $65 \%$ of variance for the theory-driven scales, and explained more than $42 \%$ of the variance in the Greek scale (Doulkeridou et al., 2010; Kudláček et al., 2002). In Polish version PCA explained $66 \%$ of the total variance. These observations suggest that the ATIPDPE and the revised version are valid and reliable tools for use in non-English speaking countries.

The differences in factor structures, observed in the Polish study, may be attributed to cross-cultural differences reflected in the education system in the studied countries. For example items 8 and 12, which in the English revised original scale loaded in negative outcomes for students, where in the Polish version, they loaded in the negative outcomes for teachers. This might be partially explained by the difference in the term inclusion across particular cultural contexts (Starczewska et al., 2012), as well as by the fact that in Poland, teachers are responsible for preparing programs for all age groups, and held accountable by the Ministry of Education for the performance of children (Polish Ministry of National Education, 2014). Additionally, students' educational achievements are based on the teachers' evaluation that recognizes the students' level of progress in mastering knowledge and skills (Polish Ministry of National Education, 2014).

The results of this study indicated the importance of understanding the cross-cultural context of adaptation when explaining variations in the factor structure in the ATIPDPE-R scale. It should be treated as a single study where factors measuring particular components might 
have influenced the factor structured observed in different countries. The results of the factor analysis provide clues as to where variation occurs while emphasizing the importance of reflecting on the sampling design, when adapting an instrument to the specific language and cultural background.

\section{Limitations}

This study was conducted only among in-service, active teachers working in different primary and secondary schools. However, it only included teachers from southern Poland, so it is difficult to say whether including teachers from other regions of the country, particularly those with different economic dynamics would change the factor structure of the scale. Also, the larger proportion of teachers with previous experience with people with disabilities may be an indication that only those individuals chose to participate in the survey.

\section{Conclusions}

The original factor structure of the ATIPDPE-R remained stable and resulted in similar or slightly higher reliability coefficients than those obtained for subscales for Polish adaptation. The findings of this study allowed concluding that ATIPDPE-R-PL measured the same three components as the original version; however specific items varied from the original ones. Based on analysis, it can be summarized that the presented results support the thesis that the instrument is a reliable and valid measurement tool for Poland.

In relation to ATIPDPE-R-PL the authors have made recommendations for further studies and include: re-evaluating the PL survey if used for PE teachers' with items 7 and 11 taken out, re-evaluating instrument on a group of pre-service PE teachers, surveying teachers at a number of other teacher preparation institutions around the country, and further investigating of the attitude of Polish in-service and pre-service PE teachers, and also include ensuring adequate representation of participants.

\section{Conflict of interest}

There were no conflicts of interest.

\section{References}

Ajzen, I. (1991). The theory of planned behaviour. Organizational Behaviour and Human Decision Processes, 50, 179-211.
Ajzen, I. (2005). Attitudes, personality and behaviour (2nd ed.). Berkshire, United Kingdom: Open University Press.

Ajzen, I., \& Fishbein, M. (1980). Understanding attitudes and predicting the social behavior. Englewood Cliffs, NJ: Prentice Hall.

Avramidis, E., \& Norwich, B. (2002). Teachers' attitudes towards integration/inclusion: A review of the literature. European Journal of Special Needs Education, 17, 129-147.

Bartoňová, R., Kudláček, M., \& Bressan, L. (2007). Attitudes of future physical educators towards teaching children with disabilities in physical education in the republic of South Africa. Acta Universitatis Palackianae Olomoucensis. Gymnica, 37(4), 69-75.

Bełza, M. (2014). Szkolnictwo specjalne w Polsce - różne formy organizacji [Special education in Poland - different forms of organization]. Katowice, Poland: University of Silesia.

Breckler, S. J., \& Wiggins, E. C. (1992). On defining attitude and attitude theory: Once more with feeling. In A. R. Pratkanis, S. J. Breckler, \& A. C. Greenwald (Eds.), Attitude structure and function (pp. 407-427). Hillsdale, NJ: Erlbaum.

Cronbach, L. J. (1951). Coefficient alpha and the internal structure of tests. Psychometrika, 16, 297-334.

Di Nardo, M., Kudláček, M., Tafuri, D., \& Sklenaříková, J. (2014). Attitudes of preservice physical educators toward individuals with disabilities at University Parthenope of Napoli. Acta Gymnica, 44, 211-221.

Doulkeridou, A., Evaggelinou, C., \& Kudláček, M. (2010). Components of attitudes toward the inclusion of students with disabilities in physical education in the ATIPDPEGR Instrument for Greek physical educators. Acta Universitatis Palackianae Olomucensis. Gymnica, 40(4), 63-68.

Downs, P., \& Willams, T. (1994). Students attitudes towards integration of people with disabilities in activity setting: A European comparison. Adapted Physical Activity Quarterly, 11, 32-34.

Education Research and Development Centre Report. (2001). Raport o sytuacji osób niepetnosprawnych w Polsce [The situation of persons with disabilities in Poland]. Retrieved from http://www.cbe.ahe.lodz.pl/archiwalna cbrk/sytuacja\%20osob.pdf

Folsom-Meek, S. L., \& Rizzo, T. L. (2002). Validating the Physical Educators' Attitude Toward Teaching Individuals with Disabilities III (PEATID III) Survey for Future Professionals. Adapted Physical Activity Quarterly, 19, 124-154.

Hardman, K. (2008). The situation of physical education in schools: A European perspective. Human Movement, 9, $5-18$.

Kudláček, M. (2007). Components of attitudes towards inclusion of students with physical disabilities in physical education in the revised "ATIPDPE-R" instrument/scale for prospective Czech educators. Acta Universitatis Palackianae Olomucensis. Gymnica, 37(1), 13-18.

Kudláček, M., Blanková, B., \& Filipčič, T. (2007). Indicators of attitudes towards inclusion of students with physical disabilities in PE in the "ATIPDPE-SL" instrument for prospective Slovene physical educators and general educators. Kinesiologia Slovenica, 13(2), 43-51.

Kudláček, M., Válková, H., Sherrill, C., Myers, B., \& French, R. (2002). An inclusion instrument based on planned 
behavior theory for prospective physical educators. Adapted Physical Activity Quarterly, 19, 280-299.

Martin, K., \& Kudláček, M. (2010). Attitudes of pre-service teachers in an Australian university towards inclusion of students with physical disabilities in general physical education programs. European Journal of Adapted Physical Activity, 3, 30-48.

Morgulec-Adamowicz, N., Molik, B., Kosmol, A., Bednarczuk, G., Błeszyński, J. J., Kaźmierska-Kowalewska, K. M., ... Woynarowska, B. (2015). Adaptowana aktywność fizyczna dla fizjoterapeutów [Adapted physical activity for physical therapist]. Warsaw, Poland: Państwowy Zakład Wydawnictw Lekarskich.

O’Brien, D., Kudláček, M., \& Howe, P. D. (2009). A contemporary review of English language literature on inclusion of students with disabilities in physical education: A European perspective. European Journal of Adapted Physical Activity, 2, 46-61.

Omianowski, M. (2008). Dziecko niepetnosprawne na lekcji wychowania fizycznego $w$ szkole masowej [Child with disability in physical education class in mainstream school] Retrieved from http://wychowaniefizyczne.pl/userfiles/_ download/inne_michniep.pdf

Papadopoulou, D., Kokaridas, D., Papanikolaou, Z., \& Patsiaouras, A. (2004). Attitudes of Greek physical education teachers toward inclusion of students with disabilities. International Journal of Special Education, 19, 104-111.

Polish Ministry of National Education. (2014). Ocenianie na zajęciach wychowania fizycznego [Students evaluation in physical education]. Retrieved from https://men.gov. $\mathrm{pl} /$ zycie-szkoly/abc-wychowania-fizycznego/6-ocenianiezajec-wf.html

Rizzo, T. L., \& Vispoel, W. P. (1991). Physical educators' attributes and attitudes toward teaching students with handicaps. Adapted Physical Activity Quarterly, 8, 4-11.

Sherrill, C., \& O’Connor, J. (1999). Guidelines for improving adapted physical activity research. Adapted Physical Activity Quarterly, 16, 1-8.

Starczewska, A., Hodkinson, A., \& Adams, G. (2012). Conception of inclusion and inclusive education: A critical examination of the perspectives and practice of teachers in Poland. Journal of Research in Special Educational Needs, 12, 162-169.

System Edukacji Oświatowej. (2014). Retrieved from http:// www.cie.men.gov.pl/index.php/dane-statystyczne/1391

Táboas-Pais, M. I., \& Rey-Cao, A. (2012). Disability in physical education textbooks: An analysis of image content. Adapted Physical Activity Quarterly, 29, 310-328.

Tripp, A., \& Rizzo, T. (2006). Disability labels affect physical education. Adapted Physical Activity Quarterly, 23, 310-326.

Zajączkowska, J. (2014). Jak umożliwić dziecku z niepetnosprawnościa ruchowa udziat w lekcjach wychowanie fizycznego? [How to enable a child with physical disability participate in physical education classes?]. Warsaw, Poland: Ośrodek Rozwoju Edukacji.

Zimbardo, P. G., \& Leippe, M. R. (1991). The psychology of attitude change and social influence. New York, NY: McGraw-Hill. 